\title{
Extent of a Social Base of a Political Regime as a Determinant of Its Authoritarian Nature
}

\author{
Apanasenko T. E \\ Vaganova Ballet Academy, St. Petersburg, Russia; Email: apanassenko2008@mail.ru
}

Doi:10.5901/ajis.2015.v4n3s1p24

Abstract

Extent of a social base of a political regime as a determinant of its authoritarian nature. Political science features one specific trend. The authoritarian nature of a political regime is measured as if the latter is independent - using Marx terms - from its social and economic base and - using a common sense language - from the recipient of its benefits which are generated by triggering of the political regime's authoritarian component. This seems obvious in relation to political science, being the bad sheep in the family. In fact, borrowing from R. Heilbroner, political science was designed to disguise social order by the social system, to hide exploitation by exposing calculations and rational choices in the first place. For those who do not fall for the idea of political science aimed at analyzing the superstructure in isolation from the base, thereby failing to grasp the essence of the facts, it is obviously impossible to build a society serving workers' interests without dictatorship as it supposedly requires overcoming resistance from exploiting classes. Or is it possible yet? Apparently, there is a robust theoretical basis for nonviolent methods of societal transformation. To put it into perspective, the main question is whether it is possible to forge an equal and fair society of common welfare without establishing an authoritarian political regime serving workers' interests. Searching for the answer to this question, this research focuses on a more specific problem, namely the relation between the political regime's degree of authoritarianism and the extent of its social base. Ancient Greek polises of 400-130 BC form the empirical foundation for this research.

Keywords: dictatorship, authoritarianism, totalitarianism, democracy, liberal ideology, political science, Marxism, social and economic basis, political superstructure, Ancient Greek policies, political regime, a political regime's authoritativeness degree, width of a social base, political regime's social base, correlation coefficient.

\section{Theoretical Framework}

In this research four ideas are developed.

1. Attributes of a political regime examined without defining whose interests it protects are void.

2. Political science disregards the above mentioned idea not owing to its ineptitude to understand it or assess its accuracy but due to the public order that requires a justification to the dominance of the exploiting class.

We expand on this vision below.

A class willing to transform a society is also eager to have the true idea of the society. (Indeed, in order to change something it is desirable to know for sure how it works.) This class is unsatisfied with the existing reality, whereas the class satisfied with the existing reality is rather willing to maintain the status quo. It is easier to preserve the status quo than to change it. Therefore, it is not necessary to have the true idea of the society to maintain the status quo. The idea of a society that conceals the reality is associated with more benefits. It brings a moral justification to one's dominance and prevents the opponent from acquiring the necessary accurate idea of the reality.

When completing the public order, scientific thought does not necessarily do it consciously, more often it occurs unconsciously.

3. A political regime with a strong repressive machinery can serve humane purposes better than a liberal political regime on condition that for the benefit of the exploited class, the first improves living conditions of the larger population.

4. The binding character of the link between the phenomenon of a political regime and the dominant position of the exploiting or exploited class is another relevant issue. In other words, a political regime with a strong repressive machinery can protect the interests of both exploiting and exploited classes, whereas a liberal political regime usually benefits the exploiting class. It can still be established to serve the needs of the exploited class but only when the exploiting class is ousted from its dominant position.

The question this research seeks to answer is whether it is always necessary to establish a political regime with a 
strong repressive machinery to protect the interests of the exploited class.

There is a solid theoretical basis both to support and reject this hypothesis.

With the aim to put forward the right solution, we turn to empirical evidence using methods of the general statistical theory. The degree of authoritarianism for a given political regime is represented by the variable $y$, social base extent is the variable $x$. We calculate the correlation ratio between the two variables.

In support of Idea 1 we rely on the theoretical tradition of classical Marxism.

In support of Idea 2 we rely on the concept of Robert Heilbroner (Heilbroner 1993).

To show how scientific thought unconsciously completes the public order we use examples from O. Spengler "The Decline of the West" (Spengler 1991), M. Foucault "Words and Things" (Foucault 1966), K. Marx "Theory of surplus value" (Marx 1863) and other politological works by K. Marx (Marx 2007), F. Engels (Engels 1884) and G. Duby (Дюби 1990).

According to S. Freud's theory (Freud 1927), vital interests containing in the actor's subconscious predetermine his optimal behavior and its rationalization in the conscious.

To back Idea 3 we turn to classical Marxism and T. Mommsen's works (Mommsen 1854-1856) together with politological concepts of social democracy as opposed to legal democracy.

In the theoretical tradition of classical Marxism we find the affirmative answer to the question raised in Idea 4. Theories of nonviolent transformation methods found in social and democratic movements, gandhism and its modifications, in turn, grant the negative reply.

In this research we set aside theories and get to use empirical evidence as a tool to find the answer to the question from Idea 4 by applying the methods of the general statistical theory.

\section{Objectives}

The main objective is to understand whether there is a correlation between the degree of authoritarianism of a political regime and the extent of its social and economic base, to define its positive or negative sign and calculate its ratio.

Should a high positive correlation ratio be established, the research achieves the following subgoals:

1. Proof of failure of opportunistic social and democratic ideas, Gandhism and its modifications;

2. Empirical evidence supporting the ideas of classical Marxism that provide for a need to set a strong repressive machinery to protect the interests of the exploited class;

3. Empirical evidence supporting the idea that a political regime with a strong repressive machinery can serve humane purposes better than a liberal political regime on condition that for the benefit of the exploited class the first improves living conditions of the larger population;

4. Empirical evidence supporting the idea that attributes of a political regime examined without defining whose interests it protects are void;

5. Empirical evidence supporting the idea that political science disregards the above mentioned concept not owing to its ineptitude to understand it or assess its accuracy but due to the public order that requires a justification to the dominance of the exploiting class.

Should the correlation ratio not be established or should it be negative, a new objective must be set, which is to develop nonviolent societal transformation methods for the benefit of workers.

\section{Discussion}

The concept that stipulates that attributes of a political regime examined without defining whose interests it protects are void, apparently, has not been subjected to a thorough theoretical analysis for when classical Marxism was fledgling, the political science restricting itself by dealing with substructural issues did not exist yet. Thus, attributes of a political regime were not considered as a separate topic of its own right. They received this status later with the development of theories of totalitarianism, authoritarianism and democracy embedded in political science. These theories have equated the antihuman Hitler authoritarianism with the authoritarianism of Napoleon and Stalin which brought social freedom and equality and to which to a large extent today we owe the opportunity to hold this conference. The emerged political science preferred to ignore and turned a blind eye to the social base of a political regime. Presumably, it makes our today's discussion a path breaker.

The speculation around the dominant social and political paradigm fulfilling the public order can be bottled down to the criticism by R. Heilbroner of the liberal social and economic ideas disguising social order by the social system. Here 
we are in agreement with R. Heilbroner as the dominant social thought tends to disregard these matters.

The hypothesis suggesting that the public order is fulfilled by social thought at the unconscious level has not been widely discussed either. It failed to come into focus of theorists though, as mentioned above, this idea could be easily found in works by K. Marx, F. Engels, O. Spengler, M. Foucault, G. Duby. In this research the theoretical basis for this hypothesis is built upon S. Freud's idea providing for the narcissism instinct to push a subject to reproduce his occasionally successful behavioral pattern. From the class protectionist perspective, a positive reaction to the challenge posed by the time pushes the creator (of an ideology, work of art or scientific theory) to reproduce the same reaction to the challenge in the future. The motivation for such reaction can still remain unknown to the creator.

The hypothesis stipulating that a political regime with a strong repressive machinery can serve humane purposes better than a liberal political regime on condition that for the benefit of the exploited class the first improves living conditions of the larger population, - was perfectly developed by a historian of Ancient Rome, defender of the poor and, thus, a firm monarchist Theodore Mommsen. Mommsen was the first to notice the hypocritical nature of the ancient liberal ideology which benefited exclusively oligarchs and accused all proxies of the democratic party - who with no exception sought an authoritarian political regime in Ancient Rome - of assaults on republican values. At the same time, the ancient liberal ideology withheld the fact that republican values did not apply for all. Nevertheless, the ancient liberal ideology has had its followers. They are incarnated in the entirety of modern liberal thought. The voice of Mommsen arguing with them remained practically the only one to be heard. We strengthen Mommsen's voice by conducting a social analysis of ancient political regimes from the Marxist position.

Finally, the last hypothesis stipulating that it is always necessary to set a political regime with a strong repressive machinery to serve the interests of the exploited class, is supported by advocates of proletariat dictatorship and argued by adepts of Gandhism and its modifications.

The findings of this research will determine which side we take.

\section{Empirical Analysis}

The random sampling under our scrutiny includes 41 Ancient Greek polises (or their groups). For the purpose of this research, we ignore Greek polises where there is no information available on their political regime or the rights of unprivileged free classes. We built up the following table where each polis is examined against two characteristics:

1. social and economic base defining the scope of unprivileged classes' rights. The existence or absence of these rights among the unprivileged will characterize the polises as "democratic" or "oligarchic" respectively. It is important to note that the term "democracy" is used in its social, not political sense.

2. political regime defined as "autocratic" or "republican".

The empirical base is presented in Table 1.

Table 1. Polises described in terms of their social and economic base and political regime

\begin{tabular}{|c|c|c|}
\hline Polis & $\begin{array}{l}\text { Social and economic base } \\
\text { (Democracy or Oligarchy) }\end{array}$ & $\begin{array}{c}\text { Political regime } \\
\text { (Autocracy or Republic) }\end{array}$ \\
\hline Megalopolis (from its foundation to the rise of Antipater's oligarchy in $322 \mathrm{BC}$ ) & Democracy & Republic \\
\hline Megalopolis 322-272 BC & Oligarchy & Republic \\
\hline Megalopolis 272-235 BC (Aristodemus and Lydiadas's tyrannies) & Democracy & Autocracy \\
\hline Lacedaemon before Cleomenes & Oligarchy & Republic \\
\hline Lacedaemon under Cleomenes & Democracy & Autocracy \\
\hline Lacedaemon under Nabis's tyranny & Democracy & Autocracy \\
\hline Lacedaemon under Aratus and Antigonus's occupation & Oligarchy & Republic \\
\hline Aetolian League & Democracy & Republic \\
\hline Achaean League & Oligarchy & Republic \\
\hline Egion & Oligarchy & Republic \\
\hline Acrocorinth & Oligarchy & Republic \\
\hline Argos & Oligarchy & Republic \\
\hline Megara & Oligarchy & Republic \\
\hline Sicyon & Oligarchy & Republic \\
\hline Corinth & Oligarchy & Republic \\
\hline Thermon & Democracy & Republic \\
\hline Thebes before 382 BC (before Spartans' invasion) & Democracy & Republic \\
\hline Thebes 382-379 BC (under the Spartans) & Oligarchy & Autocracy \\
\hline Thebes 379-362 BC & Democracy & Republic \\
\hline
\end{tabular}




\begin{tabular}{|l|c|c|}
\hline Syracuse under tyranny & Democracy & Republic \\
\hline Syracuse under the Romans & Oligarchy & Republic \\
\hline Amphipolis before 357 BC (Philip Il's invasion) & Democracy & Republic \\
\hline Amphipolis after 357 BC & Democracy & Autocracy \\
\hline Heraclea Pontica & Democracy & Republic \\
\hline Epidamnos before the democratic take over during the First Peloponnesian War & Oligarchy & Republic \\
\hline Epidamnos after the democratic take over during the First Peloponnesian War & Democracy & Republic \\
\hline Corcyra & Oligarchy & Republic \\
\hline Lefkada & Oligarchy & Republic \\
\hline Cephalonia & Democracy & Republic \\
\hline Zakynthos before Sparta's victory in the Peloponnesian War & Republic \\
\hline Zakynthos after Sparta's victory in the Peloponnesian War & Oligarchy & Republic \\
\hline Sphacteria & Democracy & Republic \\
\hline Cythera & Democracy & Republic \\
\hline Melos & Democracy & Republic \\
\hline Phocis before Myronides & Oligarchy & Autocracy \\
\hline Phocis after Myronides & Democracy & Republic \\
\hline Opuntian Locris before Myronides & Oligarchy & Autocracy \\
\hline Opuntian Locris after Myronides & Democracy & Republic \\
\hline Ozolian Locris & Democracy & Republic \\
\hline Ambracia & Democracy & Republic \\
\hline Oiniades & Democracy & \\
\hline
\end{tabular}

We shall now study the strength of a relationship between the two properties using an association coefficient. Table 2 shows derived indexes to calculate an association coefficient.

Table 2. Indexes to calculate an association coefficient

\begin{tabular}{|l|l|l|}
\hline $\begin{array}{l}\text { First property (extent of } \\
\text { a social base) }\end{array}$ & Second property (means to ensure a sustainable social and economic structure within a given extent of a social base) \\
\hline & Republic & Autocracy \\
\hline Democracy & Index a "Republic and Democracy" Index value $\boldsymbol{a}=15$ & Index $\boldsymbol{b}$ "Autocracy and Democracy" Index value $\boldsymbol{b}=8$ \\
\hline Oligarchy & Index $\boldsymbol{c}$ "Republic and Oligarchy" Index value $\boldsymbol{c}=17$ & Index $\boldsymbol{d}$ "Autocracy and Oligarchy" Index value $\boldsymbol{d}=1$ \\
\hline
\end{tabular}

Association coefficient

$$
K a=\frac{a d-d c}{a d+b c}=\frac{15 * 1-8 * 17}{15 * 1+8 * 17}=-0,8
$$

A negative value of the association coefficient indicates a sustainable inverse correlation between the properties. Thus, there is a strong opposite relationship between democracy/republic and oligarchy/autocracy.

\section{Results}

The empirical study has shown that mostly for the benefit of the exploited class, it is necessary to set a political regime with a strong repressive machinery. The empirical studies have proven the following hypotheses:

1. Opportunistic social and democratic ideas, Gandhism and its modifications turn out to find no support of its values at certain historic stages.

2. It is always necessary for the benefit of the exploited class to establish a political regime with a strong repressive machinery.

\section{References}

Droysen, Johann Gustav (2007): Geschichte des Hellenismus. DirectMedia Publ., Berlin.

Engels F. (1884): Der Urpsrung der Familie, des Privateigenthums und des Staats. Im Anschluss an L. H. Morgan's Forschungen.

Schweizeriche Genossenschaftsbuchdruckerei, Hottingen-Zürich 1884 (z. T. auch 'Verlags-Magazin', Zürich 1884).

Foucault M (1966): Les mots et les choses: une archéologie des sciences humaines. Gallimard.

Freud S (1927): Die Zukunft einer Illusion //Leipzig, Wien und Zürich: Internationaler Psychoanalyticher Verlag (Erstdruck).

Heilbroner R. L (1993):. Economics as Universal Science. Перевод Е. И. Николаенко // THESIS, N 1-1993, стр. 41-55.

Livy (1920-1940): Livy with an English translation by B. O. Foster. London, Cambridge Mass., 1920-1940; vol. I-IY.

Marx K (2007): Der achtzehnte Brumaire des Louis Bonaparte. Kommentar von Hauke Brunkhorst, suhrkamp, Frankfurt am Main 
Marx K. (1863): Theories of Surplus-Value [Volume IY of Capital]. Progress Publishers//URL: duigamo.free.fr/tpv.pdf. - 15/10/2015 Mommsen, Teodor (1854-1856). Römische Geschichte, 3 volumes (Leipzig: Reimer and Hirsel).

Polybius; Paton, W. R. (Translator) (2012). Polybius: The Histories. The Loeb Classical Library (in Ancient Greek, English, and Latin). Chicago: University of Chicago (LacusCurtius).

Spengler O (1991): The Decline of the West. Ed. Arthur Helps, and Helmut Werner. Trans. Charles F. Atkinson. Preface Hughes, H. Stuart. New York: Oxford UP

Дюби Ж. (1990): Куртуазная любовь и перемены в положении женщин во Франции XII в. // Одиссей-1990. Личность и общество. М.. C. 91-96. 